\title{
Animal bait effect on the recovery of Boophilus microplus larvae from experimentally infested grass in Morelos, Mexico
}

\author{
MANUEL FERNÁNDEZ-RUVALCABA*, JESUS F, PRECIADO-DE LA TORRE*, \\ GLORIA CORDOBA-JUAREZ**, ZEFERINO GARCÍA-VAZQUEZ*, RODRIGO ROSARIO-CRUZ* \\ and JORGE SALTIJERAL-OAXACA**
}

\begin{abstract}
To quantify the influence of the animal presence on the percentage of Boophilus microplus larvae recovery from plots experimentally infested with this tick, it was carried out a trial in Jiutepec, Morelos, Mexico, during autumn 1999 and winter 1999-2000. For this purpose there were compared four sampling methods: human walking with chaps, bovine dressed walking, double walking flagging and double walking with baited flagging. The comparison was made on tree grasses: Andropogun gayanus(gamba), Cenchrus ciliaris (buffel) and Melinis minutiflora (molasses). It was observed the same recovery efficiency of $\boldsymbol{B}$. microplus larvae in the four sampling methods studied in the two seasons. There were no statistical differences, although, there were differences $(P<0.05)$ among the grass species. The higher number of larvae recovered was recorded in the low third of the chaps, in the head and front legs of the bovine dressed, from the buffel grass and on the ventral region and legs in the other two grasses.
\end{abstract}

Key words: Boophilus microplus, Larvae, field sampling, grasses, host.

\section{INTRODUCTION}

The recovery and quantification of different developing stages of the cattle tick Boophilus microplus has been recognized as an important topic because of several reasons related to the control of ticks among them is the possibility of correlation of the free living stages in the pastures and the parasitic stages on the bovine ${ }^{1}$ as well to know the level of infestation of the paddocks along the seasons of the year ${ }^{2,3}$. However it requires reliable and accessible sampling techniques ${ }^{4}$. Three basic techniques have been used for ticks sampling from the vegetation: direct manual collection, dragging of cotton surfaces (flagging) and attractant traps with $\mathrm{CO}_{2}$ and alive animals 5 .

The most commonly used method has been the dragging method due to its accessibility and low cost, however there is a wide world controversy about the reliability, efficiency or security of these kind of methods ${ }^{6,7}$.

In a trial with Dermacentor andersoni, it was established that the larval population on the grass measured by dragging methods can be correlated with the parasite population on the host ${ }^{8}$.

\footnotetext{
* Centro Nacional de Investigaciones Disciplinarias en Parasitología Veterinaria, Km 11.5 Carretera Federal Cuernavaca - Cuautla, Progreso, Municipio de Jiutepec, Morelos, C.P. 62500, México A P. No. 206 CIVAC, México. Phone: 0173-192848. FAX 01777-3-205544, E-mail: fdezm@pavet.conacyt.inifap.mx; rfdez51@yahoo.com

** Universidad Autónoma Metropolitana - Unidad Xochimilco. AP. 23-181 CP.04960, Coyoacan, México, D. F.
} 
Comparisons were made among three sampling devices in Puerto Rico ${ }^{6}$. The authors compared the collecting efficiency of three dragging techniques for the larval stage of $B$. microplus, found that there was wide variability between techniques and they suggest the convenience of testing other experimental designs focused to diminish this variability.

The $\mathrm{CO}_{2}$ traps are attractive traps for ticks without using animals ${ }^{9}$, however other authors opine that would have to consider their use, due to the little size of the larvae) and the same authors suggest the requirement of different quantities of $\mathrm{CO}_{2}$ to attract nymphs or adults of Amblyoma americanum ${ }^{5,10}$, and suggest that It would have to consider too, their relative short distance of horizontal migration capability ${ }^{6,14}$.

For Amblyoma triguttatum it has been observed that the attraction techniques with $\mathrm{CO}_{2}$ are better than those flagging, but it was a sure method only for nymphs and adults not for larvae ${ }^{12}$. In other experiment it was found that $\mathrm{CO}_{2}$ using as attractant, was more efficient than dragging techniques, but only for host seeking stages $^{8}$. However in another experiment it was found that $\mathrm{CO}_{2}$ traps were very effective for the sampling of Ixodes dammini ${ }^{13}$.

Studying the field sampling of Amblyoma hebraeum, has been found that this specie needs high concentration of $\mathrm{CO}_{2}$ or the presence of a bovine or ovine for the stimulation of these ticks because there was not response to the stimuli of low concentrations of $\mathrm{CO}_{2}$, human presence or vibration produced by walking ${ }^{14}$.

In a trial about the sampling of Amblyomma variegatum on pastures under tropical conditions it was concluded that due to the difficult to obtain dry ice as a font of $\mathrm{CO}_{2}$ and problems to preserve it for some time before field trials in tropical conditions it would be good involve cattle $^{15}$.

Comparing techniques for I. dammini, determined that the flagging and walking techniques, (the former derived from the latter), could be sloped by human sampling preferences, for this reason is recommended that the same people should make comparative studies ${ }^{16}$. However walking techniques are more effective than flagging if human presence is considered risk factor for the humantick meeting, but the inmature stages of this tick that seeks host at ground level in the litter, are poorly sampled by walking techniques, resulting to be better method for I. dammini, the using of mice samplers when it was compared against flagging at ground level ${ }^{16}$. However, when great areas, as the case of some zones in Africa and for the sampling of a wide range of tick species, the flagging method has showed to be more accessible and reliable ${ }^{17}$.

Due to the controversy existing about the free life-stages sampling of ticks, is convenient to test different methods or modalities of a sampling technique considering the characteristics of the place, tick specie, stage, and kind of experiment. In the case of B. microplus which is a tick that seeks its host in the upper third of the grass mainly, there is doubt in the authors of this experiment, about the reliability of the flagging method to collect larvae in the lower parts of the grass at the sampling moment, because flagging methods are dragged almost exclusively in the upper third of the vegetative status.

To find adequate methods of sampling $B$. microplus larvae in Morelos, Mexico, it was carried out this work involving the natural host of this tick and comparing between different modalities of sampling methods with the purpose of quantifying the influence of host presence on the percentage of B. microplus larvae recovery from experimentally infested plots with three grass species at the sampling moment.

\section{MATERIAL AND METHODS}

Eighteen experimental plots of $35 \mathrm{~m}^{2}$ were used; Three species of grasses were seeded: Cenchrus ciliaris (buffel grass), Andropogun gayanus ( gamba grass) and Melinis minutiflora (molasses grass), with five repetitions each specie. They were established in an area of the Ejido Progreso, at the municipality of Jiutepec, Morelos, Mexico located at $18^{\circ} 53^{\prime}$ latitude north, $99^{\circ} 09^{\prime}$ longitude west, altitude of 1350 over the sea level. The clime is tropical sub humid, annual average temperature of $22^{\circ} \mathrm{C}$, rainfall of 800 $1100 \mathrm{~mm}$. The soil is vertical kind, clayey, black in colour, regular stony, moderate permeability and with irrigation.

The seeding was realized in summer 1997 in a previously prepared ground, dividing the plots of $35 \mathrm{~m}^{2}$ in five transects of $1 \mathrm{~m}$ wide $\mathrm{x} 5 \mathrm{~m}$ long and $0.5 \mathrm{~m}$ of separation between transects. There were used $12 \mathrm{~kg} / \mathrm{Ha}$ of comercial seed of buffel and gamba grass seeded on four furrows $(20 \mathrm{~cm}$ 
between them) by transect and with 4 ton/Ha of vegetative material of molasses grass ${ }^{18}$. Shrubs removing, fertilization and maintenance cuttings were made handy. The watering was made regularly during the establishment of the grasses and later only one watering by season was allowed. The transects (repetitions) were arranged under a totally random blocks experimental design with five repetitions per treatment. Previously to the larvae releasing was made a grass cutting and then were released $5,000 \mathrm{~B}$. microplus larvae per repetition of a susceptible strain to the organophosphate and free of hemoparasites which were reproduced by infesting a Holstein male bovine, of approximately $200 \mathrm{~kg}$. with (1 g of egg) approximately 20,000 B. microplus larvae and it was confined in isolation.

The treatments were the sampling techniques: T1.- Chaps, which consisted in a Human walking with sampling chaps, T2.-Dressed bovine, was a bovine walking with sampling dress, T3.flagging and T4.- flagging with baited flannel. These techniques were carried out on the grasses buffel (C. ciliaris), gamba (A. gayanus) and molasses ( $M$. minutiflora), the sampling time for all the techniques was one minute on each repetition.

In the treatment 1 (chaps), the sampling dress was one flannel of $1 \mathrm{~m}^{2}$ for each leg of the person who performed the sampling ${ }^{16}$. In the treatment 2 the bovine was dressed with flannel excepting the tail, eyes and lips. In treatment 3 the sampling device consisted in $1 \mathrm{~m}^{2}$ flannel fastened from one extreme by a wooded rule 9 . In treatment 4 the flannels used for sampling were previously rubbed on a bovine, to impregnate it of the bovine's odour.

In treatment 1 and 2 the walking were performed on a plot of $5 \times 1 \mathrm{~m}$. In treatments 3 and 4 , the flag was only sweep on the vegetative stratus, because the person who holds the device, walks along an adjacent path free of vegetation; all the walking were of 1 minute in duration. Larvae identification and counting were made with the aid of a stereoscopic microscope, sectioning the chaps in five sampling height ranges (of $20 \mathrm{~cm}$ ), and by corporal areas of the bovine skin.

The data obtained were captured in an Excel work-sheet and analysed by Andeva and average comparison, by minimal significance difference under a factorial arrangement $3 \times 4$ with five repetitions by season ${ }^{19}$ (factor a: species, factor b: sampling technique).

It was recorded in autumn 1999 the number of recovered larvae by flagging in the three grass species during eight consecutive samplings with five repetitions each one and the data obtained were analysed by a factorial arrangement $3 \times 8^{19}$

\section{RESULTS}

On the autumn, the buffel grass (C. ciliaris) showed higher larvae recovery averages with both techniques, flagging and baited flagging: 82 and 98 respectively, there was statistical difference $(\mathrm{p}<0.05)$ whit that obtained by the other two techniques 61 by chaps and 44 by dressed bovine, but these values are statistically similar with that found in A. gayanus on autumn and 51, 57 and 69 with baited flannel, dressed bovine and chaps respectively.

It was observed the same behaviour about the larvae recovery in the four sampling techniques studied: In M. minutiflora in the two seasons it was found between 0.3 - 8 larvae; in A gayanus on winter 17- 35 larvae, without statistical differences (Table 1), however, between the averages of $A$. gayanus on autumn with 26 larvae obtained with flagging and with the averages obtained from $C$. ciliaris, that obtained the greatest averages $(\mathrm{p}<0.05)$ by flagging and flagging with baited flannel on autumn,82-98 larvae, and winter, 34 - 50 larvae, and by dressed bovine with flannel, the larval recovery was lesser, 44 on autumn and 14 on winter.

It was found too, a significant statistical difference by specie effect between $M$. minutiflora and A. gayanus and C. ciliaris (Table 1). The location of larvae was higher in number, but without statistical difference, in the lower sections of the chaps, in head and anterior extremities of the dressed bovine (sampling dressing) for buffel grass and in ventral part and extremities of the bovine for the other two grasses (Table 2).

The results of the experiment of consecutive weekly samplings on autumn 2000 had statistical differences between species and between samplings. Table 3 showing differences in the seasons averages of the recovered larvae. 
Table 1. Boophilus microplus larval recovered averages by four sampling techniques from three foraging grasses in Autumn 1999

Sampling technique

Human with chaps

Bovine with sampling vestiment

Double walking flagging

Baited flannel (with double walking flagging)
C. ciliaris

$61 \pm 24^{\text {bc }}$

$44 \pm 18^{\text {cd }}$

$82 \pm 45^{\mathrm{ab}}$

$98 \pm 19^{a}$ foraging grasses

A. gayanus

$69 \pm 33$ abc

$57 \pm 28$ bcd

$26 \pm 19$ de

$51 \pm 31^{\text {bcd }}$
$M$ minutiflora

$4 \pm 3.2^{\mathrm{e}}$

$8 \pm 2.6^{\mathrm{e}}$

$3 \pm 3.5^{\mathrm{e}}$

$3 \pm 4.4^{\mathrm{e}}$

a, b, $c$ : $\mathrm{V}$ alues with different literal are different $(\mathrm{P}<.05)$.

Table 2. Boophilus microplus larval recovery averages by four sampling techniques from three foraging grasses in Winter 99-2000

Sampling technique

Human with chaps

Bovine with sampling vestiment

Double walking flagging

Baited flannel (with double walking flagging) foraging grasses

C. ciliaris
$22+17^{\mathrm{cd}}$
$14+30^{\mathrm{cd}}$
$34+33^{\mathrm{ab}}$
$50+25^{\mathrm{a}}$

A. gayanus

$17+8$ cd

$25+50^{\mathrm{abc}}$

$33+12^{\mathrm{ab}}$

$35+13^{\mathrm{ab}}$
$M$ minutiflora

$2.6+2.2^{\mathrm{d}}$

$1.4+2.8^{\mathrm{d}}$

$3.0+3.2^{\mathrm{d}}$

$0.4+0.6^{\mathrm{d}}$

a, b, c: Values with different literal are different $(\mathrm{P}<.05)$.

Table 3. Number and location of Boophilus. microplus larvae recovered by chaps and bovine with sampling dressing techniques from three foraging grasses on autumn 1999

Chaps

Specie and

$\begin{array}{lccc}\text { Hight }(\mathrm{cm}) & \text { C. ciliaris } & \text { A. gayanus } & \text { M. minutiflora } \\ & 52 & 54 & 52 \\ 0-20 & 21 & 15 & 1.6 \\ 20-40 & 24 & 22 & 2 \\ 40-60 & 11 & 31 & 0.2 \\ 60-80 & 4 & 1 & 0 \\ 80-100 & 1 & 0 & 0 \\ \text { Total } & 61 & 69 & 4\end{array}$

Dressed Bovine

foraging grasses
C. ciliaris
A. gayanus
M. minutiflora

\begin{tabular}{lrrl} 
Head & 59 & 6 & 0 \\
Anterior & 20 & 15 & 1 \\
extremities & & 22 & 3 \\
Ventral Part & 9 & 11 & 2 \\
Posterior & 8 & 2 & \\
extremities & & 56 & 0 \\
Dorsal part & 2 & 98 & \\
Total & 98 & \\
\hline
\end{tabular}

Table 4. Number of Boophilus microplus larvae recovered from three foraging grasses by flagging in eight samplings (autumn 2000)

\begin{tabular}{lccc}
\hline Sampling date & C. ciliaris & A. gayanus & M.minutiflora \\
October 24 & $865^{\mathrm{a}}$ & $551 \mathrm{bc}$ & $45 \mathrm{e}$ \\
November 7 & $461 \mathrm{c}$ & $89 \mathrm{e}$ & $22 \mathrm{e}$ \\
November 16 & $709 \mathrm{ab}$ & $180 \mathrm{de}$ & $7 \mathrm{e}$ \\
November 23 & $460 \mathrm{c}$ & $571 \mathrm{bc}$ & $17 \mathrm{e}$ \\
November 29 & $533 \mathrm{bc}$ & $363 \mathrm{~cd}$ & $14 \mathrm{e}$ \\
December 5 & $389 \mathrm{~cd}$ & $100 \mathrm{e}$ & $5 \mathrm{e}$ \\
December 12 & $11 \mathrm{e}$ & $24 \mathrm{e}$ & $3 \mathrm{e}$ \\
December 19 & $55 \mathrm{e}$ & $39 \mathrm{e}$ & $4 \mathrm{e}$ \\
Mean & $435^{\mathrm{a}}$ & $240 \mathrm{~B}$ & $15 \mathrm{C}$
\end{tabular}

$\mathrm{a}, \mathrm{b}, \mathrm{c}$ : Values with different literal are different $(\mathrm{P}<0.05)$. A, B, C: Values with different literal are different $(\mathrm{P}<$ $0.05)$.

Table 5. Climatic values under field conditions for the study period

\begin{tabular}{lcc}
\hline & $\begin{array}{c}\text { Mean } \\
\text { Temperature }\end{array}$ & $\begin{array}{c}\text { Relastive } \\
\text { humidity }\end{array}$ \\
Autumn 1999 & 24.5 & 63 \\
Winter 1999-2000 & 18.6 & 32 \\
\hline
\end{tabular}




\section{DISCUSSION}

The information obtained in this work coincides with that reported by several authors $3,6,8,9,11,16,20$, about the reliability in the larvae recovery of several sampling techniques; due to generally the response depends of multiple factors as age of ticks, climatic conditions, vegetative stratus, natural resistance of the sampling animal, preferences of the person who make the sampling among others. In this work, it was minimised the natural resistance of the host covering totally the animal surface, although we suggest that the $\mathrm{CO}_{2}$ and the bovine's odour were blocked too, because of the values obtained with dressed bovine were lesser than that obtained by flagging with baited flannel which had the odour pheromone from the bovine due to the strong friction on a bovine before they were used and that for the bovine had not this characteristic. The climatic influence was corroborated comparing autumn and winter (the best and the worst season).

\section{RESUMEN}

Para cuantificar la influencia de la presencia animal en la recuperación de larvas de pastos infestados experimentalmente, se realizó un ensayo en otoño 1999 e invierno 1999-2000. Para ello se compararon 4 formas de muestreo y 3 tipos de pastos. No hubo diferencias en la recuperación de larvas entre las 4 formas, pero $\mathrm{si}$, entre los tipos de pastos $(\mathrm{p}<0,05)$.

\section{REFERENCES}

1.- BARNARD D R. Amblyomma americanum: Comparison of populations of ticks free living stages on pastures and parasitic on cattle. Ann Entomol Soc 1981; 74: 507.

2.- FALCO R. C , FISH D. The comparison of methods for sampling the deer tick, Ixodes dammini, in a Lyme disease endemic area. Exp Appl Acarol 1992; 14: 165-73.

3.- FAO. El control de las garrapatas y de las enfermedades que transmiten. 1987; Vol 1 Roma. pp. 138-77.

4.- SUTHERST W R, WHARTON H R, UTECH W. P K. Guide to studies on tick ecology. Division of Entomology. Commonwealth Scientific and Industrial Research Organization, Australia, Technical Paper 1978; 14: 3549.

5.- KOCH H G, MCNEW W R. Sampling of lone star ticks: Dry ice quantify and capture success. Ann Am Soc Entomol 1982; 75: 579-82.
6.- ZIMMERMAN H R, GARRIS I G. Sampling Efficiency of three dragging techniques for the collection of non parasitic Bouphilus microplus (Acarida: Ixodidae) larvae in Puerto Rico. J Econom Entomol 1985; 78: 627-31.

7.- DANIELS J T, FALCO C R, FISH D. Estimating population and drag sampling efficiency for the blacklegged tick (Acari:Ixodidae). J Med Entomol 2000; 37: 357-63.

8.- WILKINSON R P, GREGSON D J. Comparison of sampling methods for recording the numbers of rocky mountain wood ticks (Dermacentor andersonii) on cattle and range vegetation during control experiments. Acarología 1985; 26: 131-9.

9.- CORNET $P$ J, DEGALLIER $N$, HERVE $P$ J. Description of a sledge for tick sampling (Acarida: Ixodidae). Acarología 1984; 25: 17-9.

10.- KOCH H G, MCNEW W R. Comparative catches of field populations of I. ricinus and its use. Ann Am Soc Entomol 1981; 74: 498-500.

11.- GODDARD J. Ecological studies of Ixodes scapularis (Acarida: Ixodidae) in central Mississipi. Lateral movement of adult ticks. J Med Entomol 1993; 30: 824-6.

12.- GUGLIEMONE A A, MOREHOUSE E D, WOLF G. Atraction to carbon dioxide of unfed stages of Ambyomma trigutatum under field conditions. Acarologia 1985; 26: 123-9.

13.- FALCO R C, DURLAND F. The use of carbon dioxide tick traps for sampling Ixodes dammini Acarology 1989; 25: 29-33.

14.- NORVAL R A, YUNKER C E, BUTLER J F. Field sampling of unfed adults of Amblyomma hebraeum Koch. Exp Appl Acarol 1987; 3: 21, 3-7.

15.- BARRE N, GARRIS G I, LORVELEC O. Field sampling of the tick Amblyomma variegatum (Acari: Ixodidae) on pastures in Guadeloupe; attraction of $\mathrm{CO}_{2}$ and or tick pheromones and conditions of use. Exp Appl Acarol Feb; 1997; 21: 95-108.

16.- GINSBERG H S, EWING C O. Comparison of flagging, walking, trapping, and collecting from hosts as sampling methods for northern deer ticks, Ixodes dammini, and lone-star ticks, Amblyomma americanum (Acari: Ixodidae). Exp Appl Acarol Sep; 1989; 7: 313-22.

17.- SPICKETT A M, HORAK I G, BRAACK L E O, VAN ARK H. Drag sampling of free-living ixodid ticks in the Kruger National Park. Onderstepoort J Vet Res 1991; 58: 27-32.

18.- HUMPHREYS L R. A Guide to better pastures for the tropics. Wright Stephenson Co., Sidney, Australia. 1980.

19.- PAGANO M, GAUVREAU K. Principles of Bioestatistics p 145. 172 Duxbury Press. U.S.A 1993.

20.- FERNÁNDEZ-RUVALCABA M. Comparación de cuatro técnicas de colecta de larvas de Boophilus microplus bajo condiciones de campo en infestación controlada. Téc Pec México 1996; 34: 175-81.

Aknowledgements: This work was performed as part of the project "Ecological strategies for the control of the cattle tick Boophilus microplus in Mexico", partially funded by SAGAR-CONACYT PROJECT K0083-9702. 